\title{
Methods of Assessing the Risks Associated with Lack of Water Supplies, Water Safety Plan for National Conditions.
}

\author{
Sławomir Rybka \\ Department of Environmental Protectionand Water Management \\ ul. Tkaczowa 134 Boguchwala Town Municipality \\ e-mail: slawomirrybka@vp.pl
}

\begin{abstract}
Article shows the desire to obtain risk-control options, and bringing it to a tolerable level. Subjects were ways of managing and dealing with risk. Methods of dealing with aspects of the protection of industrial buildings and high-risk critical infrastructure vulnerability analysis methodology to the loss of integrity. Also a set method to deal with aspects of the protection of industrial buildings and high-risk critical infrastructure that is the analysis of susceptibility to loss of integrity. The article also presents the basic principles of water safety plan based on national and foreign research publications. In the next part of article WSP methodology was concluded, outlining the actions which use significantly reduces the risk of threats that could lead to supply of contaminated tap water or total interruption of its supply. In further considerations the most important steps in creating WSP were presented. In the final section the principle of modular computer system operation that is used for network management for urban water supply in Rzeszow was presented.
\end{abstract}

Key words: risk, water safety

\section{Introdution}

The main objectives of the WSP (called Water Safety Plan) is to ensure good practice in the delivery of water by minimizing contamination of water sources, reduce or eliminate pollution through treatment processes, to prevent secondary pollution in the distribution network and internal systems [1]. WSP is a way to supply safe water for human consumption by meeting the standards of health care. Currently, the assessment of water security is limited to test its quality, and too little attention is paid to proactive safety management of water. World Health Organization (WHO) has identified five key components that are required to comply with the provision of safe drinking water:

- the establishment of water quality standards in terms of microbiological and physicochemical,

- evaluating the system of collective water supply SCWS (System of Collective Water 
Supply) to determine whether the system supplies water to the consumer do not have a secondary water pollution, and whether the water in the consumer still meets all standards of quality,

- monitoring SCWS, the implementation of specific measures to control water quality at various stages of production and distribution to ensure consumer safety,

- management plans, documenting the results of the evaluation and monitoring to help in the planning of actions to be taken during normal operation and in emergency situations to ensure the supply of "safe" water

- an independent public health through safe water supply.

Steps 2 through 4 inclusive are called. WSP. The plan is to provide an improved tool to manage risk so as to ensure security of supply of drinking water. Typically, for the preparation, implementation and evaluation of the WSP is responsible supplier of drinking water. WSP is largely based on risk analysis and management in all it's subsystems SCWS, ranging from inclusion in the raw water source and ending with the installation of an internal object of the consumer. Through good practice in water supply means: to minimize contamination of water sources, reduce or virtually eliminate pollution through treatment processes, to prevent secondary pollution in the process of storage and distribution, both in the distribution network as well as internal systems. SCWS General analysis aims to identify potential risks in all parts of the system by determining the level of risk and appropriate procedures for its control or the possible reduction in order to ensure supply of safe drinking water. It's necessary to simultaneously comply with the standards of the target values, which are responsible for ensuring the health of consumers of water [2]. To present the assumptions for the WSP in relation to national conditions, taking into account the specificities SCWS for the city of Rzeszow.

\section{Methodology WSP}

The traditional approach to water quality and management of its security relied on testing water quality at the stage of recognizing the source, and then after various cleaning processes and in certain points of the distribution network, are elected rather public institutions or facilities. Problem it's also the fact that the waiting period for results of some tests is quite long and there may be cases where it is too late to apply preventive measures. Another problem is that the tests are underused because the sampling frequency is too small relative to the amount of produced water. Therefore, water safety is at risk especially in terms of bacteriological quality and for systems with high water production. The study also showed that the water pathogens may be present, with the commonly used indicators of the bacteriological quality of the disease can still be transmitted by water, despite the fact that the water meets the standards in terms of bacteriological. The results are not available immediately after sampling, and therefore there is the possibility of providing water to the recipient and may not be used until test results are known, and therefore preventive action will no longer be possible. The problem, in particular, relates to the microbiological quality of water, where the results of most studies are available only after several hours of incubation. Use of the WSP provides greater certainty as to the quality and allows for more efficient asset 
management, but these solutions are not yet widely used in developing countries. One reason for this is "crisis management", which is the norm in many water suppliers in developing countries. WSP uses many elements of the HACCP (Hazard Analysis and called Critical Control Points), whose purpose is to analyze the risks and the designation of critical control points system, WSP also uses elements of other solutions, such as ISO 9000 and the concept of Total Quality (TQM). WSP is an improved tool for risk management, to ensure supplies of safe drinking water. Water Safety Plan sets out:

- the risks to which the water is exposed and the level of risk associated with each of them,

- how specific risks will be controlled,

- how the control measures will be monitored

- how the operator can determine the loss of control,

- what actions are necessary to restore control,

- how to verify the effectiveness of the system.

Through the development of WSP, managers and operators of water supply systems will gain a thorough knowledge of the system and manage the risks to which it is exposed. This knowledge can then be used to develop operational plans and identify key priority actions. Developing WSP also specifies what additional training and projects are required to improve the performance of safe water supply. How to develop a water safety plan? Develop a plan for water security includes:

- ways to prevent pollution of water sources

- the reduction or elimination of pollution of water abstracted in order to meet standards for water safety,

- prevention of recontamination during storage and distribution of water.

Water supplier wanting to meet the above requirements should:

- appoint a team that knows, understands the system and its ability to produce good quality water,

- determine where the contamination may arise under the collective water supply (SCWS) and what are the possibilities of a controlled

- to validate the methods to control hazards

- establish a monitoring system to check whether it is supplied clean and safe water,

- periodically check for properly in the implementation of water safety plan. Introduction of water safety plans in developing countries is a bit more difficult than in developed countries, because:

- limited data availability, many developing countries have only recently introduced systems for collecting and storing data

- there are no specific development plans,

- pollution caused by inadequate access to sewer may cause contamination of water supply networks,

- lack of knowledge of the system, much of the information on the network may not be available

- availability of equipment and manpower is less than in developed countries.

To be effective implementation of the WSP, it is important that the person previously responsible for the management involved in developing security plans. This process is essential to gain support for changes in working practices and to actively promote water 
safety. A key aspect of strategies to engage on the part of management is to provide a clear and coherent arguments for the fact that the adopted security plans are beneficial to the organization and better than other measures. This process must fall within a broad planning process. WSP should be used instead of conventional water quality monitoring. The first step in the implementation of the management of the WSP is to prepare a short briefing note. Note this should include information on current activities that are compatible with those of security, and on what new methods of work will be needed to implement and what will be the impact on costs. It is also important to note that this include information about why security plans are relevant activities for water work. The actual approach will vary depending on specific environmental conditions in which the supplier of water works, different aspects of the WSP will be attractive to managers in different circumstances. First of all, WSP enables operators to learn the system, and their actions may be more effective, because they spend more time to identify and control risk, not only for its analysis [5]. In further considerations, presented the most important steps in setting up WSP; eight major steps used to develop an effective WSP for SCWS. Step 1: Appoint a steering group WSP an important element is the establishment by the management team responsible for the development, implementation and periodic updating of the WSP. The team should include individuals with appropriate qualifications, ranging from engineers responsible for design, operation and maintenance of the system, microbiologists and chemists through the inspection of water quality, and ending with the technical staff and operators involved in the operation of the system. The team that can not fail to scientific representative in the field of health. After completing the team leader should emerge who will be responsible for steering the work and report to the leadership of their progress. Development and implementation of a WSP is possible without external support, however, if it is needed a company may find help from specialized experts.

Step 2: Documentation and description SCWS. In the development of the WSP records is essential that team members have a good knowledge of both project documentation and procedures SCWS operating system, it is important to also know the contractors who are served by the provider. This documentation should include a description of all processes that may affect water quality and complete information about the various stages of work SCWS such as: recognition of water, process water treatment, storage, distribution. It is also necessary to create a detailed description of the area, which supports SCWS and a statement of the legal requirements and standards to be met by the system.

Step 3: Evaluation of the-map approach, the plan SCWS To carry out the systematic identification of hazards and events associated with each element of the system block diagram. The team responsible for creating the WSP should know and understand the relationship between a source of danger, and his movement in the environment and the presence of water. The next step is to evaluate the risks tailored to the SCWS. Hazard identification must be based on knowledge and experience of the water supply company. The creation of the so-called. priority list of risks allows you to sort out risks identified from those that require immediate action by those whose risk is tolerated. Risk analysis process is action to identify threats, assess risks and to assess it's size.

Step 4: Controlling hazards. Safeguard measures are individually matched to the needs of the system, so that their type and number are different for each SCWS. It is necessary to implement effective protection measures for each identified hazardous event, the risk is 
significant. Any detention must be described in a precise and universally understood. Standard operating procedures for improving the effective implementation of each task.

Step 5: Plan to improve and modernize. The next step after the identification of significant risks is a plan to improve and upgrade, you must also specify the target dates to implement plans, and appoint persons who are held accountable. Elementary action is to implement incremental improvements using the programs short, medium and long term. Such programs should reflect the priorities and available resources. Particular importance is to improve operational procedures and management less important are research and development increases the potential, and to the need for capital investment. An important aspect is to improve communication, reporting and drafting minutes of incidental events.

Step 6: Preparation of management procedures. During normal operation of the system are implemented standard operating procedures, other procedures are carried out during the event incident and corrective actions. Very helpful in implementing plans for improvements and modernization is to talk with knowledgeable staff on the performance of their activities, and the obligation to draw up reports by operators of incidents of potentially dangerous situations and exceptional circumstances. It is also important to define the responsibilities of the workers, as well as drawing up a clear description of the actions necessary to implement in case of deviations from the normal. The description should include location of equipment, spare and repair, and a description of relevant activities of logistics and engineering.

Step 7: Verification and audit. This step allows you to obtain evidence that the WSP was developed and implemented correctly. After verifying the quality of water we receive about the quality of the water produced meets the established quality requirements. Operational audit assesses whether the WSP is implemented in accordance with the proposed.

Step 8 Periodic review. This stage is one of the key elements to successfully implement the plan. Regular reviews enable an assessment of whether the entire WSP is still valid. The review is based on an analysis of data gathered from monitoring, drawing conclusions, the performance update and implement new procedures for military aircraft when it is justified. Inspections must be carried out regularly at designated intervals and always after an emergency or potentially dangerous, incidentally. Of review may be a change in the risk assessment. The review may also cause the changes in WSP, modernization and the introduction of improvements, all changes are the result of the review should be documented [6] [8].

\section{Water safety plan for the city of Rzeszow.}

In considering the application for a WSP Rzeszów agglomeration on the basis of data on MPWiK (municipal water and wastewater company) Rzeszów agglomeration company supplying the water, we looked at the activities of the company aimed at providing safe water supplies. One of the major elements of the monitoring work of the modernized station and waterworks Zwięczyca SCWS network is a SCADA system (called Supervisory Control and Data Acquisition). It's a system for supervising the process of technological or productive. Its main functions include the collection of current data (measurements), their visualization, process control, alarming, and archiving data. SCADA is the name of a computer system that serves as the parent in relation to the programmable logic controllers, PLC (Programmable 
Logic Controller in English) and other devices. In general, the PLCs are connected directly to the actuators (valves, pumps, etc.) and measuring (temperature sensors, level, etc.) and collect data from the object and perform automatic control and regulation algorithms. Through the PLC goes into the computer system and there are archived and processed into a form more user-friendly. Transmission system operators are asking the general parameters of the process or lead the process in manual mode. This figure shows the functions of a SCADA system used on the waterworks SCWS Zwięczyca that are part of the agglomeration of Rzeszow.

Modern SCADA systems take over all functions of monitoring and control, including decision-making processes. Fully replace the routine control of a dispatcher can monitor and possibly control the process manually if needed. SCADA system is a module of the computerized management system for urban water supply network of Rzeszow. The whole system has an open modular structure and consists of four basic modules: a system with industry-oriented GIS (Geographical Information System in English) to generate digital maps, the water supply network, the SCADA system for monitoring SCWS, CIS (Customer Information System) data provider Web users and quantities consumed by them water, and a mathematical model of water supply and coupled to the multiobjective optimization algorithm. The monitoring system consists of the measuring points located on the water supply network system for transmission of measurement data to the SCADA system database and a program visualization, archiving and data processing (ProconWin). The monitoring system installed in Rzeszow for the system now covers 30 sampling points installed in the source network, reservoirs, pumping stations in the zone and the final network. Data transmission uses two systems: the system GPRS (General Packet Radio Service) mobile telephony and radio broadcasting, with the points of measurement of radio transmission are placed in the sources, reservoirs and pumping stations. The measurements from the monitoring system used to calibrate the hydraulic model of the water supply network, to verify the results of hydraulic calculations, tracking on-line network and also to detect abnormal states of this work. To achieve the latter task was developed for each measuring point known. Standard curves of flows and pressures, which are compared with measurements on an ongoing basis and in the current case of deviations greater than a specified tolerance range, there is indication of an unusual [3]. Computer systems, SCADA, CIS, and GIS are excellent tools to meet a lot of water safety plans, assumptions, any real object can be reflected in the data model of a computer system through the use of GIS systems are able to obtain, process, as well as store and share data. Using the computer systems faster and easier implementation of tasks in the enterprise allows instant access to current information stored in the database. [4]

\section{Failures of public water supply}

Incidental events and serious water pollution accidents will happen, because they are random and eliminate the risk of their occurrence to zero is almost impossible or too expensive, even if feasible. The risk represents a threat but also gives a chance, that we can distinguish two aspects of the risk of negative and positive. Danger is the cause or source of losses, is a sequence of time and proceeds in the following phases:

- danger potential

- realization of the real danger 
- the effects of hazards

Gambling is a set of conditions and circumstances under which realizes the danger of most of the water pipes in Poland as much as $65 \%$ are made of cast iron and steel, these materials are characterized by a high failure rate at a level that the impact of this fact by factors such as time of operation of these installations which dates back to 1960 in some cases even 100 years, the susceptibility corrosion and cracking defects in material, and improper performance of the installation. The process of implementing a system entails various risks of one of them is the risk of selection of contractors is also found in the selection of participants in the investment process, a designer, process engineer, contractor, construction manager and inspector. Weaknesses can be stuck in the wrong choice by the people employing them in institutions, but also the selection of participants in the process, including in the way of conducting tenders for the design, and construction works. Another risk, which is subject to investment risk is a lack of experience of the main participants in the investment process, each member of the investment process (investor, designer, inspector, construction manager, construction worker, technologist ,...) may not have sufficient qualifications and relevant experience to conduct entrusted the work in the proposed project investment, and therefore can make mistakes. Due to the irreversibility and uniqueness of the investment process errors made during the design and Implementation have a major impact on the level of investment risk. Water Losses occure through the entire process of production and distribution of water, beginning and ending with a shot of the consumer. Most of the losses borne by the water company water supply due to a leak, the cause of the poor condition of the network and the high pressure in the network. Water loss through leaks in the system for water companies are wery significant because it does not receive payment for a product which is water. A German study reported that the installation of an external leaks are from 80 to $100 \%$ of the actual water loss, and the most common causes of these losses are:

failures of water pipes, leaking pipes and water supply arms, leaks water through fire hydrants, gray material defective network, theft of water.[5]

The volume of water loss depends on:

the technical condition of pipes and fittings, pipe diameter and age, material from which the cord was performed, density of water supply connections, density of the network cables, ground conditions, water pressure in the network and its watches in the daily cycle. Factor influencing the amount of water losses are soil conditions in which the installation is located. Sandy land characterized by the fact that the water leak quickly rises to the top and easy and above all, it is possible to quickly detect failures. Different matter is in the case of rocky and coarse songs here water penetrates into the soil with the consequence is that leaks are more difficult to detect, last longer, causing heavy loss of water. Leaks installation in cohesive soils are also difficult to detect, except that a variable cohesive soil saturated with water, may have a greater propensity to move, the land of coherence are also more aggressive to some materials than land flowing. Pressure fluctuations in the diurnal cycle affect the failure rate, and the water flow of the damaged network elements [10] . 


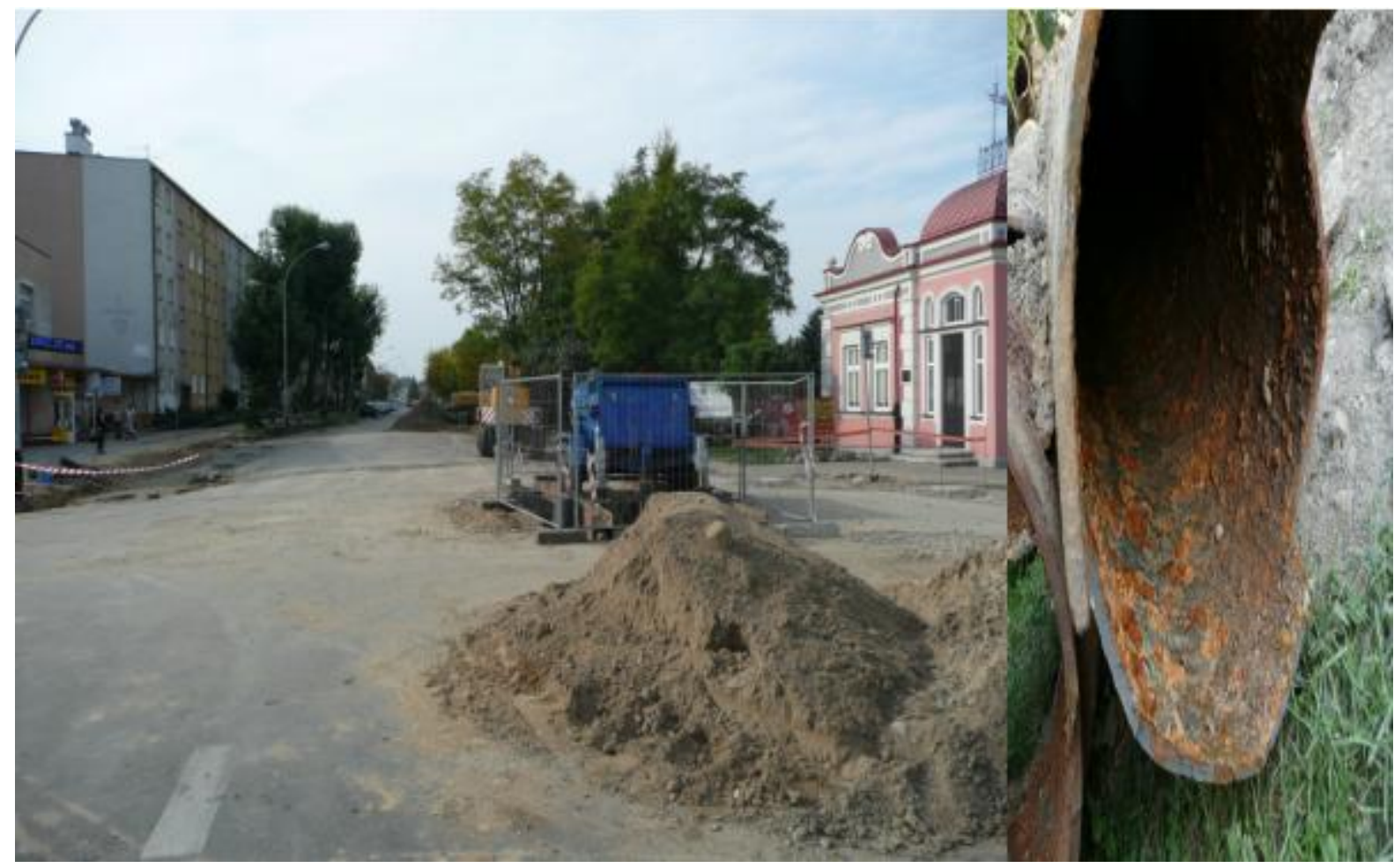

Figure 1: The breakdown of the water-supply in Krakowska street in Rzeszów, brought to the closed of the road for many days

\section{Economic and environmental benefits arising from the use of trenchless methods}

In the urban roads and intersections with heavy traffic it's difficult to imagine the construction or rehabilitation of underground networks traditionally in the trenches. Such implementation would be a very serious obstacle to both pedestrians and traffic. Another factor in favor of the use of trenchless technology, this situation is the dense network of underground pipes different from their connections and sewers. Work in pits may also constitute a threat to the foundations of nearby buildings which are often invaluable cultural wealth. Using trenchless technology in densely urbanized and populated, it is much better than using conventional methods remediation. The use of trenchless method is only burdened with commuting problems within the hole start, intermediate and final, in the case of sewage within the well sewage. Application in the same situation most traditional methods leads to a complete temporary closure of the road. The advantages of the technology tranchless and benefits of their use are presented below. A significant decrease in costs work where pipes are founded on a great depth because, unlike traditional trenchless technology in the work of the cost increase is not associated with the depth of installation channel. The need to carry out the works below ground water table also does not increase the cost of the operation using trenchless methods. Using trenchless technology treatments below the groundwater table does not apply to drainage works which are very costly and time consuming. Time the execution of 
works is several times faster compared to traditional methods which greatly affect the decrease in costs. Weather conditions or time of year are also a factor that could greatly affect the efficiency of traditional weather conditions are very important factor. Time performance of the work methods of excavation is in effect a much shorter, easier to predict and execute within a given period. No need for trenching causes that there is no cost associated with the implementation of security boardings, or the use of protective cages. There is no need to replace the soil in the trench. The contractor shall not be held so the costs associated with delivery of formwork assembly and dismantling of the security is not necessary expensive equipment to dismantle a road surface, construction and backfilling the trench and repavement performance. The time of these activities takes a long time. Since the rare right after back filling can be made in pavement in the final version the most common are cases where the ground requires a stabilization time before the intended road surface. In case of trenchless construction of new lines is only exported a volume equal to the volume of land arranged pipes. Renewing tranchless sewer lines in the large majority of cases does not require any excavation and provide access to cable drains. After the repair methods of excavation does not result in waste associated with replacement of old pipes with new trenchless methods in an old canal is repaired from the inside without dismantling, are exported and subject to recovery, disposal or storage. In addition to cost savings achieved further significant reduction of environmental nuisances associated with reducing the amount of generated gas, noise, dust and contaminants that arise in the case of trenching works. Groundwater in the area of trenchless methods are not polluted which is an additional factor significantly preferred to minimize the environmental harm of the work. Work in the trenches often cause damage to trees and shrubs leading to their withering, trenchless methods, the occurrence of such situations is minimal. Slight risk of structural damage to buildings located near the pipe repaired traditional methods actually bring much. Threat are the vibration caused by the operation of heavy equipment, landslides from slopes to the interior of the excavation, drainage of the soil in the trench located near the foundation of the building. When using traditional methods, there is a strong risk of damage to other wires or cables in the case of trenchless methods could be reduced to a tolerable level. There is also a nuisance for residents, customer nearby institutions, and user the road, no need to organize detowr causing traffic jams, increased fuel consumption, loss of time and frustration leading to security and increase in the number of collisions and accidents. Costs associated with claims of losses caused by shop owners and service businesses also fall to a minimum [7] [3].

\section{Conclusion}

WSP is essentially aimed at protecting human health, therefore, one of the main objectives is to ensure the good practice in the delivery of water. Practical ways of linking water safety plans, computer systems and network management problems associated with it will be the subject of further studies and their results will be presented in subsequent articles.

\section{References}

[1] Rak, J. (2005). Podstawy bezpieczeństwa systemów zaopatrzenia w wodę. Lublin: Komitet Inżynierii Środowiska PAN, Wydawnictwo-Drukarnia LIBER DUO KOLOR. 
[2] Godfrey, S., Howard, G. (2004). Water Safety Plans (WSP) for Urban Piped Water Supplies in Developing Countries. Loughborough University.

[3] Kolonko, A. (1998). Klasyfikacja bezodkrywkowych metod przywracania sprawności technicznej rurociągów podziemnych Gaz. Woda i Technika Sanitarna, Volume 2.

[4] Asklew, T., Kalinowski, M. (1996). Konferencja pt. „, Modernizacja komunalnych wodociągów i kanalizacji - aspekty finansowe, organizacyjne i techniczne. Warszawa.

[5] Kolonko, A., Madryas, C. (2006). Renowacja przewodów wodociagowych metoda cementowania. Bielsko-Biała.

[6] Jabłonowski, P., Kwietniewski, M., Leśniewski, M., Rechnio, T. Badania niezwodności elementów sieci kanalizacji rozdzielczej w Wołominie. In VI Konferencja Naukowo Techniczna Nowe technologie w sieciach i instalacjach wodociągowych i kanalizacyjnych, Marzec 2006, Wisła.

[7] Rak, J. (2004). Istota ryzyka w funkcjonowaniu systemu zaopatrzenia $w$ wodę. Rzeszów: Oficyna Wydawnicza Politechniki Rzeszowskiej.

[8] Godfrey, S., Howard, G. (2004). Water Safety Plans (WSP) for Urban Piped Water Supplies in Developing Countries. Loughborough University.

[9] Kołodziński, E., Fedorowicz, R., Malinowska, A. (2000). Komputerowe wspomaganie zarządzania eksploatacją sieci wodociągowej i kanalizacyjnej. In Materiaty I Sympozjum naukowego Systemy Informacji o Terenie $w$ zarzadzaniu, dowodzeniu $i$ kierowaniu, Jelenia Góra.

[10] Tchórzewska-Cieślak, B. (2008). Niezawodność i bezpieczeństwo systemów komunalnych, na przykładzie systemu zaopatrzenia $w$ wodę. Rzeszów: Oficyna Wydawnicza Politechniki Rzeszowskiej. 